\title{
Bovine babesiosis and anaplasmosis complex: diagnosis and evaluation of the risk factors from Bahia, Brazil
}

\author{
Complexo tristeza parasitária bovina: diagnóstico e avaliação dos fatores de risco na Bahia, Brasil \\ Lucimar Souza Amorim ${ }^{1}$; Amauri Arias Wenceslau²* Fábio Santos Carvalho ${ }^{1}$; \\ Paulo Luíz Souza Carneiro ${ }^{3}$; George Rêgo Albuquerque ${ }^{2}$
}

${ }^{1}$ Programa de Pós-graduação em Ciência Animal, Universidade Estadual de Santa Cruz - UESC, Ilhéus, BA, Brasil

${ }^{2}$ Departamento de Ciências Agrárias e Ambientais, Universidade Estadual de Santa Cruz - UESC, Ilhéus, BA, Brasil

${ }^{3}$ Departamento de Ciências Biológicas, Universidade Estadual do Sudoeste da Bahia - UESB, Jequié, BA, Brasil

Received March 28, 2014

Accepted August 4, 2014

\begin{abstract}
Direct diagnoses were made by using - blood smears and nested PCR (nPCR) tests on 309 blood samples from crossbred dairy cattle in the municipality of Ibicaraí, Bahia. From diagnostic blood smear slides, the observed parasitic frequencies were $31.1 \%$ for Anaplasma marginale and 20.4\% for Babesia sp. From nPCR diagnoses, they were 63\% for A. marginale, $34 \%$ for Babesia bigemina and $20.4 \%$ for Babesia bovis. There were significant differences $(\mathrm{P}<0.01)$ between the two diagnostic methods (nPCR and blood smear slides). The compliance obtained from the kappa test was 0.41 and 0.48 for $A$. marginale and Babesia sp., respectively. The tick samples from the six farms analyzed using nPCR were only positive for $A$. marginale. Evaluation of the risk factors relating to the presence of ticks and the age of the animals showed that there was a significant association $(\mathrm{P}<0.01)$ with the frequency of animals infected with both pathogens. Therefore, under the conditions studied, nPCR proved to be a good tool for diagnosing the agents of the bovine babesiosis and anaplasmosis complex because of its sensitivity and specificity in comparison with blood smears. The municipality of Ibicaraí is an area with endemic prevalence of bovine babesiosis and anaplasmosis confirmed by $\mathrm{nPCR}$ and $A$. marginale is the main agent of the disease.
\end{abstract}

Keywords: Bovine Babesiosis and Anaplasmosis Complex, blood smear, nPCR, risk factors.

\section{Resumo}

Realizou-se o diagnóstico direto por esfregaço sanguíneo e nested PCR (nPCR) em 309 amostras de sangue de bovinos mestiços leiteiros provenientes do município de Ibicaraí, Bahia. A frequência observada no diagnóstico por lâminas de esfregaço sanguíneo foi 31,1\% para Anaplasma marginale e 20,4\% para Babesia sp. Enquanto que no diagnóstico por nPCR foi $63 \%$ para A. marginale, $34 \%$ para Babesia bigemina e 20,4\% Babesia bovis. Verificaram-se diferenças significativas $(\mathrm{P}<0,01)$ na comparação entre os dois métodos de diagnósticos (nPCR e esfregaço sanguíneo). A concordância ao teste KAPPA obtida foi de 0,41 e 0,48 para A. marginale e Babesia sp., respectivamente. As amostras de carrapatos das seis propriedades analisadas por nPCR foram positivas apenas para $A$. marginale. Na avaliação dos fatores de risco verificou-se que a presença de carrapato e idade dos animais apresentaram associaçáo significativa $(\mathrm{P}<0,01)$ com a frequência de animais infectados por ambos os patógenos analisados por nPCR. Portanto, nas condiçôes estudadas, a nPCR revelou-se uma boa ferramenta para diagnóstico dos agentes do complexo tristeza parasitária bovina (TPB) devido a sensibilidade e especificidade, quando comparado ao esfregaço sanguíneo. O município de Ibicaraí apresenta-se como uma área endêmica para TPB com prevalência comprovada através de nPCR e, $A$. marginale o principal agente encontrado.

Palavras-chave: Complexo TPB, esfregaço sanguíneo, nPCR, fatores de risco.

*Corresponding author: Amauri Arias Wenceslau, Departamento de Ciências Agrárias e Ambientais, Universidade Estadual de Santa Cruz - UESC, Rodovia Jorge Amado, Km 16, Salobrinho, CEP 45662-900, Ilhéus, BA, Brasil, e-mail: wenceslau@uesc.br 


\section{Introduction}

In Brazil, the main etiological agents of the bovine babesiosis and anaplasmosis (BBA) complex are Anaplasma marginale Theiler, 1910, Babesia bovis Babes, 1888, and B. bigemina Smith; Kilborne, 1893. The first is a bacterium belonging to the order Rickettsiales, of the Anaplasmataceae family (DUMLER et al., 2001), and the other two are protozoa belonging to the Babesiidae family. The main vectors of Babesia are Rhipicephalus (Boophilus) ticks (BOCK et al., 2004). Anaplasma marginale is transmitted mechanically via blood-contaminated fomites or mouthparts of biting flies (SHIMADA et al., 2004). Biological transmission of $A$. marginale is effected by ticks. In general, the tick vectors of $A$. marginale include Rhipicephalus spp., Dermacentor spp. (D. albipictus, D. andersoni, D. hunteri, D. occidentalis and D. variabilis) and Ixodes ricinus, while Amblyomma spp. do not appear to transmit $A$. marginale (KOCAN et al., 2004). Although transovarial transmission has been reported for some ticks, it has not been demonstrated for R. microplus (RIBEIRO et al., 1996; KESSLER, 2001).

Agents for the BBA complex are distributed across almost the entire Brazilian territory and their occurrence is directly related to the distribution of the vectors, which find ideal conditions for development in countries with tropical and subtropical climates. This complex of diseases causes economic losses and is a limiting factor for the growth of cattle, due to high rates of morbidity and mortality in these animals (PEREIRA, 2006).

The epidemiological profile of the BBA complex of a region can be determined by evaluating several factors, such as breed, age, climate, stress and pasture management. Regions can be defined as free, unstable or stable. Areas that are free from BBA are those where weather conditions are not favorable for development of the vector (BERTO et al., 2008). Unstable areas are those where the climatic conditions and/or livestock management affect occurrences of BBA at certain periods of the year (KESSLER et al., 1983, BARROS et al., 2005). In stable areas, the disease is present throughout the year, and therefore the animals have high enough levels of antibodies to promote protection that can be passed to calves with the colostrum (MADRUGA et al., 1984; GONÇALVES, 2000; OSAKI et al., 2002). It is necessary to know the epidemiological situation of a region in order to measure occurrences of outbreaks and the need to implement preventive measures (GUIMARÃES et al., 2011).

In most regions of Brazil, BBA presence is epidemiologically stable, with a few areas of instability (ARTILES et al., 1995; GUIMARÃES et al., 2011). A similar situation is observed in the state of Bahia, where the areas of instability are strictly due to semi-arid climatic conditions that are unfavorable for development of the vector (ARAÚJO et al., 1998).

Worldwide, many techniques have been standardized to indirect and direct diagnose the BBA complex. The diagnosis consists of indirect detection of antibodies against the agents of the BBA complex. Several serological tests are used for detection of bovine babesiosis and anaplasmosis, and the following stand out among them: the rapid conglutination test (RCT), latex agglutination, hemagglutination, complement fixation (CF) (MARANA et al.,
2006), test card (TC), indirect immunofluorescence assay (IFA) (SOUZA et al., 2001; MARANA et al., 2009), indirect enzymelinked immunosorbent assay (iELISA) and competitive ELISA (cELISA) (MARANA et al., 2009).

The BBA complex can be directly diagnosed based on viewing parasites within red blood cells in thin blood smears stained with Giemsa, or by means of parasite DNA amplification using the polymerase chain reaction (PCR) (VIDOTTO; MARANA, 2001). The parasitological examination, performed by means of blood smears, is the oldest method and is routinely used for diagnosing hemoparasites. In the acute phase of the disease, when parasitemia is high, parasites are easily detected in bovine erythrocytes (FARIAS, 1995). However, when the animals recover and become carriers with low parasitemia, viewing the parasites using this method becomes extremely difficult and may fail, since the parasite can easily be mistaken for an artifact. Thus, the sensitivity of blood smears is low and false-negative results are common (BOSE et al., 1995). However, this event is common when the technician is not trained to reach a diagnosis.

Advances in the field of molecular biology have made it possible to use parasite DNA amplification techniques as diagnostic methods. Molecular diagnosis of hemoparasites identifies the agent directly, even when the parasites are circulating in small quantities, and this method has high sensitivity and specificity in comparison with other diagnostic techniques, such as blood smears. Among the molecular diagnosis techniques, the PCR technique has been used to demonstrate the presence/absence of Babesia spp. and Anaplasma spp. in asymptomatic carrier cattle (BRITO et al., 2006).

The municipality of Ibicaraí, located in southern Bahia, stands out as a milk production region that provides raw material for the dairy industry in this state. Given the importance of the BBA complex, together with the lack of information on the epidemiology of these diseases in southern Bahia, the aims of the present study were to compare the diagnostic methods for direct blood smears and $\mathrm{nPCR}$, determine the frequency of infection by agents for the BBA complex and evaluate the risk factors associated with such infection in crossbred dairy cattle in the municipality of Ibicaraí, Bahia.

\section{Materials and Methods}

\section{Study area}

This study was conducted in the municipality of Ibicaraí, which is located in the southern region of Bahia, covering a total area of $217,914 \mathrm{~km}^{2}$, at a latitude of $14^{\circ} 51^{\prime}$ south and longitude of $39^{\circ} 35^{\prime}$ west, with an average altitude of $162 \mathrm{~m}$. The vegetation consists of seasonal and dense rain forest, with rainfall between 1200 and $1400 \mathrm{~mm} /$ year and an average annual temperature of $27^{\circ} \mathrm{C}$. The municipality has a herd of approximately 17,900 cattle, of which 4,500 are dairy cattle with an average production of 2.6 million liters/year (IBGE, 2010).

The sample size was calculated using Epi Info 6.0, taking into consideration the total population of the herd, an $80 \%$ possibility of detecting the disease with a $95 \%$ confidence interval and a 
statistical error of $5 \%$. This calculation resulted in a sample $(\mathrm{N})$ of 243 animals. However, blood samples were collected from 309, with 169 samples of adult females and 140 samples from calves of both sexes aged between one and 270 days.

Samples were collected on six farms with extensive rearing on pasture. In some cases, the cattle were given protein supplementation. The sample collection period was between November 2010 and February 2011. Blood samples (5 mL volume) were collected by coccygeal vein puncture with needle and Vacutainer tubes containing EDTA anticoagulant. The samples were packed in insulated containers with ice packs, and were transported to the laboratory for processing, on the same day.

To obtain data on the risk factors relating to the BBA complex, a questionnaire was applied, which was filled out at the time of sample collection. This contained objective discursive questions, which had the purpose of collecting information on: ticks (yes or no); flies (yes or no); animal movements (yes or no); examinations for hemoparasites (yes or no); use of larval packet test (yes or no); type of calf management (individual or collective); breed of animals (crossbred or Girolando); pasture areas; breeding systems (intensive or extensive); age (adult or calf); and sex of animals (male or female).

\section{Laboratory processing}

The blood samples collected were used to blood smears preparation, which were fixed using methanol and stained by Giemsa. To direct diagnosis, the slides were observed under an optical microscope (Olympus BX $51^{\circledR}$ ).

\section{Extraction of genomic DNA}

A volume of $300 \mu \mathrm{L}$ of each blood sample was aliquoted into $2 \mathrm{~mL}$ microcentrifuge tubes, to which $500 \mu \mathrm{L}$ of distilled water was added. This mixture was homogenized by vortexing for $30 \mathrm{~s}$ to break the cells, and was then centrifuged for 6 min at 12,000 $\mathrm{g}$. The supernatant was discarded and the pellet was eluted in T.E. (10 mM Tris-HCl, pH 8.0; 200 mM EDTA, pH 8.0; proteinase $\mathrm{K} 120 \mathrm{mg} / \mathrm{mL}$; and $1 \%$ Triton X-100). Each sample was gently stirred on a vortex and was incubated in a water bath at $50{ }^{\circ} \mathrm{C}$ for about $30 \mathrm{~min}$. Then SDS (0.5\%) was added, homogenized by vortexing for $30 \mathrm{~s}$ and incubated in a water bath for $30 \mathrm{~min}$. Genomic DNA was extracted using a mixture of phenol, chloroform and isoamyl alcohol, and was precipitated with 100\% ethanol and ammonium acetate at a ratio of $1 / 10$. The pellet was washed with $85 \%$ ethanol, resuspended in $10 \mathrm{mM}$ Tris- $\mathrm{HCl}$ ( $\mathrm{pH} \mathrm{8.0)}$ and quantified by means of spectrophotometric absorbance at $260 \mathrm{~nm}$ and $280 \mathrm{~nm}$. The DNA samples were stored at $-20^{\circ} \mathrm{C}$ in a microtube in order to perform- PCR diagnostic, later on.

To check the feasibility of total DNA extraction from the blood of crossbred cattle, reactions with primers specific to the promoter region of the DGAT1 gene (which is responsible for production of milk fat) were performed: forward - 5'-TCA GGATCCAGAGGTACCAG-3' and reverse - 5'-GGGGTCCAAGGTTGATACAG-3' (KUHN et al., 2004).

\section{$D N A$ extraction from ticks}

Around 10 teleogine ticks were collected from each animal on each of the six farms. These were fixed in ethanol and stored at $-20^{\circ} \mathrm{C}$. All the ticks collected on a single farm were mixed to form a representative sample. From each of these six samples, five subsamples were withdrawn, weighing approximately $300 \mathrm{mg}$ (around 3 to 5 ticks per sample), thus totaling 30 subsamples, in order to increase the likelihood of identifying the DNA of parasites in ticks. Each subsample was macerated with liquid nitrogen, followed by genomic DNA extraction using the same protocol as used for the blood samples.

\section{Polymerase chain reaction (PCR)}

For the molecular diagnosis of $A$. marginale, $B$. bovis and $B$. bigemina, $\mathrm{nPCR}$ reactions were performed, using the primers described in Table 1. The reactions were prepared in a volume of $25 \mu \mathrm{L}$ containing $200 \mathrm{mM}$ dNTP, $5.0 \mathrm{mM} \mathrm{MgCl}, 2 \mathrm{U}$ Taq DNA polymerase (Promega ${ }^{\circledR}$ ), 3x amplification buffer (supplied by the manufacturer), 11 pmol of every primer (Ana Ana R and $\mathrm{F}$ for $A$. marginale, $\mathrm{BoF}$ and Bor for $B$. bovis and Bilhah and Bilb for $B$. bigemina) and $60 \eta$ g of genomic DNA. The amplification protocol was as follows: initial denaturation at $95^{\circ} \mathrm{C}$ for $5 \mathrm{~min}$

Table 1. Primers used for the detection of $A$. marginale (TORIONI DE ECHAIDE et al., 1998), B. bovis and B. bigemina (FIGUEROA et al., 1993).

\begin{tabular}{|c|c|c|c|}
\hline Pathogen & Primer & $\begin{array}{c}\text { Sequence } \\
\end{array}$ & Bp \\
\hline \multirow[t]{4}{*}{ B. bovis } & $\mathrm{BoF}$ & CACGAGGAAGGAACTACCGATGTTGA & \multirow{2}{*}{350} \\
\hline & BoR & CCAAGGAGCTTCAACGTACGAGGTCA & \\
\hline & BoFN & TCA ACA AGGTACTCTATATGGCTACC & \multirow{2}{*}{290} \\
\hline & BoRN & CTACCGAGCAGA ACCTTCTTCACCAT & \\
\hline \multirow[t]{4}{*}{ B. bigemina } & BiIA & САТСТААТТТСТСТССАТАССССТСС & \multirow{2}{*}{278} \\
\hline & BilB & CCTCGGCTTCAACTCTGATGCCAAAG & \\
\hline & BiIAN & CGCAAGCCCAGCACGCCCCGGTGC & \multirow{2}{*}{170} \\
\hline & BilBN & CCGACCTGGATAGGCTGTGTGATG & \\
\hline \multirow[t]{3}{*}{ A. marginale } & Ana F & GCATAGCСТCССССТСТTTC & \multirow{2}{*}{458} \\
\hline & Ana R & TCCTCGCCTTGCCCCTCAGA & \\
\hline & AnaFint & TACACGTGCCCTACCGACTTA & 345 \\
\hline
\end{tabular}


followed by 35 cycles of $94^{\circ} \mathrm{C}$ for $1 \mathrm{~min}$, annealing at $65^{\circ} \mathrm{C}$ for 1 $\min$ for $A$. marginale, $55^{\circ} \mathrm{C}$ for $1 \mathrm{~min}$ for $B$. bovis and $64^{\circ} \mathrm{C}$ for 1 min for $B$. bigemina, and extension at $72^{\circ} \mathrm{C}$ for $40 \mathrm{~s}$, with a final step at $72{ }^{\circ} \mathrm{C}$ for $5 \mathrm{~min}$ in the MJ96G thermocycler $\left(\right.$ Biocycler $\left.^{\circledR}\right)$. The amplification products were separated on $1.5 \%$ agarose gel stained with ethidium bromide and photographed.

In the second reaction, $25 \mu \mathrm{L}$ of DNA from the product of the first reaction was used as the template. nPCR was only done with samples that did not amplify (i.e. were negative) in the first reaction. In the reaction with $25 \mu \mathrm{L}$, the primers $\mathrm{F}$ int Ana and Ana $\mathrm{R}$ were used for $A$. marginale, BoFN and Born for B. bovis and B. Bilan and BilBN for B. bigemina, with an amplification scheme similar to that used in the first reaction, except for changing the annealing temperatures, which were $65^{\circ} \mathrm{C}$ for $A$. marginale and $B$. bovis, and $69^{\circ} \mathrm{C}$ for $B$. bigemina. The amplification products were separated on $1.5 \%$ agarose gel stained with ethidium bromide and photographed.
In all reactions, positive and negative controls were used. DNA samples from Embrapa Beef Cattle in Campo Grande, Mato Grosso do Sul, were used as the positive control. The negative control, ultrapure water was used in the PCRs.

\section{Statistical analysis}

For data analysis, logistic regression was performed to construct multivariate models that could explain the dependent variables (presence of DNA de Babesia sp. and A. marginale) as a function of the 11 independent variables, dichotomously (Table 2). The independent variables were subjected to univariate analysis and those with a statistical association (here considered to be $\mathrm{P}<0.20$, using the chi-square test, for this first analysis) were tested in the multivariate model by means of the stepwise forward method (COSTA et al., 2013). The variables were included in

Table 2. Risk factors for the etiologic agents of bovine babesiosis complex in crossbred dairy cattle in the municipality of Ibicarai, BA, Brazil.

\begin{tabular}{|c|c|c|c|c|c|c|c|c|}
\hline \multirow[t]{2}{*}{ Risk factors } & \multicolumn{4}{|c|}{ Babesia sp. } & \multicolumn{4}{|c|}{ Anaplasma marginale } \\
\hline & Samples +/Total (\%) & $\mathbf{X}^{2}$ & $\mathbf{P}$ & OR (CI 95\%) & Samples +/Total (\%) & $\mathrm{X}^{2}$ & $\mathbf{P}$ & OR (CI 95\%) \\
\hline \multicolumn{9}{|l|}{ Presence of tick } \\
\hline Yes & $119 / 174(68.4)$ & 98.44 & 0.00 & $17.3(9.2-32.3)$ & $132 / 174(75.9)$ & 29.34 & 0.00 & $4.32(2.6-7.0)$ \\
\hline No & $15 / 135(11.1)$ & & & & $60 / 134(44.8)$ & & & \\
\hline \multicolumn{9}{|l|}{ Transit of animals } \\
\hline Yes & $61 / 134(45.5)$ & 0.30 & 0.57 & $1.02(0.6-1.6)$ & 83/134 (61.9) & 0.00 & 0.95 & $1.02(0.6-1.6)$ \\
\hline No & $73 / 175(41.7)$ & & & & $109 / 175(62.3)$ & & & \\
\hline \multicolumn{9}{|l|}{ Test to hemoparasites } \\
\hline Yes & $21 / 61(34.4)$ & 2.04 & 0.15 & $0.62(0.3-1.1)$ & $37 / 61(60.7)$ & 0.01 & 0.90 & $0.87(0.4-1.5)$ \\
\hline No & $113 / 248(45.6)$ & & & & $155 / 248(62.5)$ & & & \\
\hline \multicolumn{9}{|l|}{ *Adult Immersion Test } \\
\hline Yes & $21 / 61(34.4)$ & 2.04 & 0.15 & $0.62(0.3-1.1)$ & $37 / 61(60.7)$ & 0.07 & 0.90 & $0.87(0.4-1.5)$ \\
\hline No & $113 / 248(45.6)$ & & & & $155 / 248(62.5)$ & & & \\
\hline \multicolumn{9}{|l|}{ Type hutch } \\
\hline Aggregate & $109 / 256(42.6)$ & 0.21 & 0.64 & $0.83(0.4-1.5)$ & $160 / 256(62.5)$ & 0.01 & 0.89 & $1.15(0.6-2.1)$ \\
\hline Single & $25 / 53(47.2)$ & & & & $32 / 53(60.4)$ & & & \\
\hline \multicolumn{9}{|l|}{ Age of animals } \\
\hline Calves & $78 / 140(55.7)$ & 14.98 & 0.00 & $2.53(1.5-4.0)$ & $108 / 140(77.1)$ & 23.35 & 0.00 & $3.62(2.1-5.9)$ \\
\hline Cows & $56 / 169(33.1)$ & & & & $84 / 169(49.7)$ & & & \\
\hline \multicolumn{9}{|l|}{ Breed } \\
\hline Blended & $109 / 256(42.6)$ & 0.21 & 0.64 & $0.83(0.4-1.5)$ & $160 / 256(62.5)$ & 0.01 & 0.89 & $1.15(0.6-2.1)$ \\
\hline Girolando & $25 / 53(47.2)$ & & & & $32 / 53(60,4)$ & & & \\
\hline \multicolumn{9}{|l|}{ Cattle run } \\
\hline$>50$ ha & $73 / 175(41.7)$ & 0.30 & 0.57 & $0.85(0.5-1.3)$ & $109 / 175(62.3)$ & 0.00 & 0.95 & $0.97(0.6-1.5)$ \\
\hline$<50$ ha & $61 / 134(45.5)$ & & & & 83/134 (61.9) & & & \\
\hline \multicolumn{9}{|l|}{ System breeding } \\
\hline Extensive pasture & $88 / 195(45.1)$ & 0.48 & 0.48 & $0.82(0.5-1.3)$ & $123 / 195(63.1)$ & 0.10 & 0.74 & $0.83(0.5-1.3)$ \\
\hline Extensive/supplementation & $46 / 114(40.4)$ & & & & $69 / 144(60.5)$ & & & \\
\hline \multicolumn{9}{|l|}{ Sex } \\
\hline Female & $93 / 243(38.3)$ & 11.06 & 0.10 & $1.58(0.8-2.8)$ & $146 / 243(60.1)$ & 1.65 & 0.19 & $1.58(0.8-2.8)$ \\
\hline Male & $41 / 66(62.1)$ & & & & 46/66 (69.7) & & & \\
\hline \multicolumn{9}{|l|}{ Presence of flies } \\
\hline Yes & $58 / 146(39.7)$ & 1.22 & 0.26 & $0.75(0.4-1.1)$ & $95 / 146(65.1)$ & 0.31 & 0.57 & $1.17(0.7-1.8)$ \\
\hline No & $87 / 163(53.4)$ & & & & $63 / 163(55.3)$ & & & \\
\hline
\end{tabular}

*Bioassay of acaricide susceptibility by Drummond et al. (1973). 
the multivariate model if they displayed statistical significance of $\mathrm{P}<0.05$, considering also the significance level of the final model. All analyses were performed using the Epi-Info software, version 3.5.1. Principal component analysis (PCA) also was made using SAS (2003) statistical program, where the factors associated with significant effect by chi-square test were used as variables in terms of positive and negative diagnoses for $A$. marginale and Babesia $\mathrm{sp}$. The PCA is a multivariate analysis technique which consists in transforming an original set of variables into a set of transformed variables, the principal components, that retains as much of the original information in terms of total variation (CRUZ et al., 2011). The kappa test was used to measure the agreement between the tests under real conditions, in accordance with Thrusfield (1986).

\section{Results}

Amplification of total DNA extracted from the blood of crossbred cattle with primers specific to the promoter region of the gene DGAT1 resulted in fragments of $145 \mathrm{bp}$, thus proving the feasibility of analyzing DNA for use in molecular diagnosis of BBA.

The first PCR amplification resulted in fragments of $458 \mathrm{bp}$ for $A$. marginale, $350 \mathrm{bp}$ for $B$. bovis and $278 \mathrm{bp}$ for B. bigemina. The second amplification reaction resulted in fragments of $345 \mathrm{bp}$ for $A$. marginale, $290 \mathrm{bp}$ for $B$. bovis and $170 \mathrm{bp}$ for $B$. bigemina. The animals were considered to be positive for one of the three agents of the BBA complex when the amplifications resulted in the fragment patterns described above. The analysis on 309 blood samples from cattle, that were subjected to nPCR, showed that 195 (63.1\%) were positive for $A$. marginale, 105 (34\%) for $B$. bigemina and 63 (20.4\%) for B. bovis. From the blood smear slides, 96 (31.1\%) were positive for $A$. marginale and 60 (19.41\%) for Babesia sp.

In this study, $73.13 \%(226 / 309)$ of the animals that were analyzed by nPCR were found to be infected; $24.27 \%(75 / 309)$ were infected by two of the three pathogens evaluated and $10.03 \%$

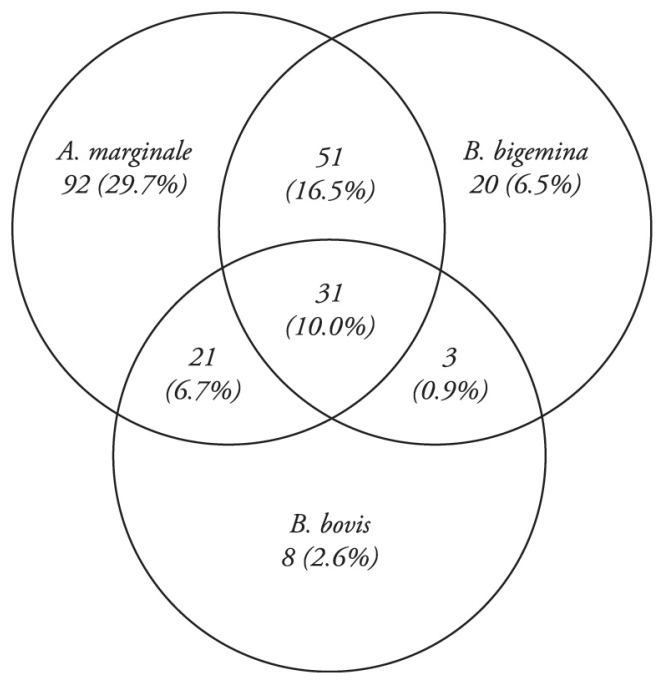

Figure 1. Venn diagram PCR results for BPS complex.
(31/309) by all three (Figure 1). A total of 24 subsamples $(80 \%)$ of ticks from the six farms that were analyzed by nPCR were positive for $A$. marginale. All the tick samples analyzed by nPCR were negative for Babesia spp.

There were significant differences $(\mathrm{P}<0.01)$ between the two diagnostic methods (nPCR and blood smear slides). Out of the 195 blood samples that were positive for $A$. marginale from nPCR, 96 (49.2\%) showed positive on blood smears (Table 3). The agreement obtained in the kappa test was 0.41 . Out of the 134 blood samples (43.4\%) that were positive for Babesia sp. from nPCR, 63 (47\%) showed positive on blood smears (Table 3). The agreement obtained in the kappa test was 0.48 .

In assessing the risk factors for the etiological agents of the BBA complex, it was found through the logistic regression, which the presence of ticks and the age of the animals showed a significant association $(\mathrm{P}<0.01)$ with the frequency of animals infected by both pathogens, in the analysis by nPCR (Table 2 and 4).

The first two principal components were sufficient to explain $81.60 \%(\mathrm{CP} 1$ and $\mathrm{CP} 2=51.70 \%=29.90 \%)$ of the variation between the positive and negative individuals for $A$. marginale. The first principal component was given by $\mathrm{CP} 1=-0.632+0.659$ * SEX * $+0.406 *$ PCARR FET, and it was observed that the variables age (FET) and presence of ticks (PCARR) were associated factors that characterize most animals with positive diagnosis. Sex has negative weighing value and was slightly associated with positive animals for this disease

For Babesia sp. was observed that the first three principal components are needed to explain $86.60 \%$ (=39.7\% CP1, CP2 and $\mathrm{CP} 3=25.6 \%=21.3 \%$ ) variance in the original data set. The first principal component was given by CP1 $=-0.584+0.648 *$ $\mathrm{SEX}^{*}+0.415 *$ FET PCARR $-0.254 *$ TESTCARR. In this component will also be highlighted the variables age (FET) and presence of ticks (PCARR), and these were the associated factors related to the majority animals with positive diagnosis. SEX and the TESTCARR (Test to hemoparasites) variables showed negative values.

\section{Discussion}

In Brazil, diagnostic techniques to investigate the molecular epidemiology of the BBA complex are little used, with only a small number of published studies. In Bahia, this is the first study in which the nPCR technique was used to detect the presence of agents for the BBA complex in crossbred cattle and ticks. The amplification patterns found in this study for B. bovis, B. bigemina and $A$. marginale were similar to those described by Figueroa et al. (1993), Torioni de Echaide et al. (1998), Moura et al. (2002) and Brito et al. (2007), who used the same sets of primers.

The southern region of Bahia is characterized as an area of enzootic stability (ARAÚJO et al., 1998), according to the concepts of Mahoney and Ross (1972). This region has annually climatic conditions that favor the development of $R$. microplus, the main vector of the agents for the BBA complex.

On the six farms analyzed, it was found that $63.1 \%$ of the animals were positive for $A$. marginale, using the nPCR diagnostic test. This was similar to what was found by Torioni de Echaide et al. 
Table 3. Comparison of PCR and blood smears as diagnostic methods of Anaplasma marginale and Babesia sp. in crossbred dairy cattle herds from the municipality of Ibicarai, BA, Brazil.

\begin{tabular}{|c|c|c|c|c|}
\hline \multicolumn{5}{|c|}{ Anaplasma marginale } \\
\hline & & \multicolumn{2}{|c|}{ PCR } & \multirow{2}{*}{ Total } \\
\hline & & Positive & Negative & \\
\hline \multirow{3}{*}{ Blood smear } & Positive & $96(49.2 \%)$ & $0(0 \%)$ & $96(31.1 \%)$ \\
\hline & Negative & $99(50.8)$ & $114(100 \%)$ & $213(68.9 \%)$ \\
\hline & Total & $195(63.1 \%)$ & $114(36.9 \%)$ & $309(100 \%)$ \\
\hline \multicolumn{5}{|c|}{ Babesia sp. } \\
\hline & & \multicolumn{2}{|c|}{ PCR } & \multirow{2}{*}{ Total } \\
\hline & & Positive & Negative & \\
\hline \multirow{3}{*}{ Blood smear } & Positive & $63(47 \%)$ & $0(0 \%)$ & $63(20.4 \%)$ \\
\hline & Negative & $71(53 \%)$ & $175(100 \%)$ & $246(79.6 \%)$ \\
\hline & Total & $134(43.4 \%)$ & $175(56.6 \%)$ & $309(100 \%)$ \\
\hline
\end{tabular}

Test $\chi^{2}(\mathrm{P}<0.01)$.

Table 4. Multivariate analysis of risk factors associated with the presence of Anaplasma marginale and Babesia sp. in crossbred dairy cattle in the municipality of Ibicarai, BA, Brazil.

\begin{tabular}{|c|c|c|c|c|c|c|}
\hline \multirow[b]{2}{*}{ Variable } & \multicolumn{3}{|c|}{ Babesia sp. } & \multicolumn{3}{|c|}{ Anaplasma marginale } \\
\hline & OR & CI 95\% & $P$ Value & OR & CI 95\% & $P$ Value \\
\hline \multicolumn{7}{|l|}{ Age of Animals } \\
\hline Calves & 2.18 & $1.24-3.81$ & 0.006 & 3.21 & $1.89-5.45$ & 0.0000 \\
\hline Cows & 1.00 & & & 1.00 & & \\
\hline \multicolumn{7}{|l|}{ Presençe of Ticks } \\
\hline Yes & 16.43 & $8.74-30.90$ & 0.0000 & 3.91 & $2.35-6.51$ & 0.0000 \\
\hline No & 1.00 & & & & & \\
\hline
\end{tabular}

(1998) in Oregon, USA, with 64\% of positive animals, and lower than what was observed by Brito et al. (2010) in Rondônia and Acre, Brazil, who found that $98.6 \%$ and $92.4 \%$ of the animals were positive, respectively, among animals aged between 4 and 12 months, using PCR in both studies. These higher results obtained by Brito et al. (2010) may have been influenced by several factors, including age, since their study was conducted exclusively using calves. In the results from the present study, the calves also showed higher values $(\mathrm{P}<0.01)$. The frequency of positive samples for B. bigemina was 34\%, similar to what was found by Smeenk et al. (2000), who observed in Zimbabwe that 35\% of the animals were positive. These findings were higher than what was found by Brito et al. (2007) in Rondônia, with a frequency of 3.09\%, also using molecular diagnostic PCR. On the other hand, 20.4\% of the animals were found to be positive for $B$. bovis, a frequency similar to what was observed by Martins et al. (2010) in Mozambique, where $27 \%$ of the animals were positive. Furthermore, mixed infections with the hemoparasites $B$. bigemina and $B$. bovis were identified and were correlated with the ticks responsible for transmitting these diseases to cattle (MARTINS et al., 2010).

As expected, the frequencies of Babesia sp. and $A$. marginale detected by DNA amplification (43.4 and 63.1\%, respectively) were significantly higher than those obtained through microscopic examination of blood smears (20.4 and $31.1 \%$ respectively) $(\mathrm{P}<0.01)$. Similar results were observed by Cassini et al. (2011) from comparing these same techniques for detecting Babesia sp. in Italy, who found that $21.6 \%$ of the animals were positive by PCR and $6.5 \%$ by blood smears. The method of microscopic examination of blood smears has low sensitivity and does not detect positive animals in the early or chronic stages of infection, when the number of circulating parasites is very low (OLIVEIRASEQUEIRA et al., 2005), although this procedure is used by veterinarians to monitoring clinical cases (SANTANA et al., 2008).

The multivariate logistic regression analysis results and principal components showed the influence of the risk factors presence of ticks and age for of $A$. marginale and Babesia sp infection. It was found that the calves were 3.62 and 2.53 times more susceptible when compared to adult cows for $A$. marginale and Babesia sp., respectively. Similar results were observed for $A$. marginale by Ashuma et al. (2013). The results of this paper disagree with Terkawi et al. (2012) that found greater positivity of Babesia in adult cattle.

The presence of ticks positive for $A$. marginale was in agreement with the findings of Shimada et al. (2004), who confirmed the presence of $A$. marginale DNA in $R$. microplus larvae by PCR. Rhipicephalus microplus is a monoxenic tick, but adult stages can migrate between animals by physical contact (MASON; NOVAL, 1981). Intrastadial transmission by male ticks may be important in maintaining the organism in enzootic areas. Transstadial 
transmission has been reported in relation to many ticks including R. microplus (CONNELL, 1974; STICH et al., 1989).

The fact that the ticks analyzed were negative for Babesia sp. does not rule out their importance as Babesia sp. vectors for the studied animals. The presence of ticks was considered to be an important risk factor $(\mathrm{OR}=16.4)$ for Babesia positive animals. These negative results can be explained by low positivity for Babesia sp. in the ticks or by molecular detection failure due to low amounts of the pathogen's DNA in the analyzed samples. In fact, transmission of $B$. bigemina and $B$. bovis by $R$. microplus has been confirmed in some reports (SPARAGANO et al., 1999; OLIVEIRA-SEQUEIRA et al., 2005).

Determination of the stability or instability profile of a region depends on assessment of several factors, such as those inherent to the animal (breed and age), along with climate change, stress management, pasture type and presence of vectors (GUIMARÂES et al., 2011). In areas of enzootic stability, immunity is acquired early enough in the life of most animals, and this is the reason that clinical disease only occurs rarely. However, management and climatic conditions can affect the immune status and tick population, making the animals susceptible. Certain risk factors may affect the presence of hemoparasites in animals, such as the presence of ticks and the age of the animals, as seen in this study, in which these two risk factors were significantly associated with the presence of $A$. marginale and Babesia sp. (Table 2). Persistent presence of ticks throughout the year allows continuous inoculation of the pathogens into animals from the time of their birth onwards, which allows them to develop specific immunity that is sufficient to make them resistant (FOLLY et al., 2009). Thus, calves have higher prevalence of agents for the BBA complex, as observed by Madruga et al. (2000) in Mato Grosso do Sul, even without evidence of clinical signs (ZAUGG et al., 1986).

Endemic (or enzootic) stability is a widely used term in the epidemiology of ticks and tick-borne diseases. The main features of endemic stability in this context are a high level of challenge with hemoparasite-infected ticks and a concurrent low incidence of clinical disease. However, Jonsson et al. (2012) disagreed with the definition of endemic stability and reliance on seroprevalence as an indicator of exposure that could be generally accepted and extrapolated to other host-tick-pathogen systems. These authors described the importance of including data generated to correlate tick infection rates by pathogens, tick infestation rates among cattle, serial seroprevalence in cattle and disease incidence among animals of diverse genotypes. Further studies are needed to confirm these claims. They concluded that the concept of endemic stability was not applicable to $B$. $t$. indicus cattle or to tick-borne diseases in which inverse age immunity (as seen in B. bovis, B. bigemina and $A$. marginale infections) is not a feature.

In short, within the conditions studied, nPCR proved to be a good tool for diagnosing BBA agents because of its sensitivity and specificity in comparison to blood smears. The municipallity of Ibicaraí presents all three parasites, and Anaplasma marginale is the main agent for BBA. Moreover, in the municipality of Ibicaraí, the factors associated with BBA that presented greatest significance were the presence of ticks and the age of the animals, in comparison with the observed frequency of BBA agents.

\section{References}

Araújo FR, Madruga CR, Leal CRB, Bastos PAS, Marques APC. Frequência de anticorpos anti-Anaplasma marginale em rebanhos leiteiros da Bahia. Arq Bras Med Vet Zootec 1998; 50(3): 243-246.

Artiles J, Alves Branco FP, Martins JR, Correa LB, Sapper MFM. Prevalência de Babesia bovis e Babesia bigemina em bovinos no estado da Bahia. Rev Bras Parasitol Vet 1995; 4(2): 187-193.

Ashuma SA, Singla LD, Kaur P, Bal MS, Batth BK, Juyal PD. Prevalence and haemato-biochemical profile of Anaplasma marginale infection in dairy animals of Punjab (India). Asian Pac J Trop Med 2013; 6(2):139144. http://dx.doi.org/10.1016/S1995-7645(13)60010-3

Barros SL, Madruga CR, Araújo FR, Menk CF, Almeida MAO, Melo EPS, et al. Serological survey of Babesia bovis, Babesia bigemina, and Anaplasma marginale antibodies in cattle from the semi-arid region of the state of Bahia, Brazil, by enzyme-linked immunosorbent assays. Mem Inst Oswaldo Cruz 2005; 100(6): 513-517. PMid:16302060. http://dx.doi. org/10.1590/S0074-02762005000600003

Berto RS, Faustino MAG, Melo LEH, Alves LC, Madruga CR, Almeida $\mathrm{MAO}$, et al. Frequência de anticorpos IgG anti-Babesia bovis e antiBabesia bigemina em bovinos no Município do Paudalho, Zona da Mata do Estado de Pernambuco. Med Vet 2008; 2(3): 9-12.

Bock R, Jackson L, De Vos A, Jorgensen W. Babesiosis of cattle. Parasitology 2004; 129(Suppl S1): S247-S269. PMid:15938514. http:// dx.doi.org/10.1017/S0031182004005190

Bose R, Jorgensen WK, Dalgliesh RJ, Friedhoff KT, De Vos AJ. Current state and future trends in the diagnosis of babesiosis. Vet Parasitol 1995; 57(1-3): 61-74. http://dx.doi.org/10.1016/0304-4017(94)03111-9

Brito LG, Oliveira MCS, Moura MMF, Silva Netto FG, Cavalcante FA, Marim AD, et al. Extraçáo de DNA a partir de coágulos sanguíneos bovinos. Brasília: EMBRAPA [online]. 2006 [cited 2011 Set 10]. Available from: http://www.cpafro.embrapa.br/publicacoes/2006/ bpd43_dnabovinos.pdf.

Brito LG, Oliveira MCS, Silva Netto FG, Cavalcante FA. Estratégias de prevençáo e controle da tristeza parasitária bovina (TPB) a partir da avaliação molecular da infecção em rebanhos criados em diferentes regiôes fisiográficas dos estados de Rondônia e Acre. Brasília: EMBRAPA [online]. 2007 [cited 2011 Set 10]. Available from: http://www.cpafro. embrapa.br/media/arquivos/publicacoes/cot329_tristezaparasitaria.pdf

Brito LG, Oliveira MCS, Rocha RB, Silva Netto FG, Marim AD, Souza GCR, et al. Anaplasma marginale infection in cattle from southwestern Amazonia. Pesq Vet Bras 2010; 30(3): 249-254. http://dx.doi. org/10.1590/S0100-736X2010000300011

Cassini R, Marcera F, Di Regalbono AF, Cancrini G, Gabrielli BS, Morettic AR, et al. New insights into the epidemiology of bovine piroplasmoses in Italy. Vet Parasitol 2011; 184(1): 77-82. PMid:21864982. http://dx.doi. org/10.1016/j.vetpar.2011.08.004

Connell ML. Transmission of Anaplasma marginale by the cattle tick Boophilus microplus. Queensland J Agric Anim Sci 1974; 31(3): 185-193.

Costa VMM, Ribeiro MFB, Duarte ALL, Mangueira JM, Pessoa AFA, Azevedo SS, et al. Seroprevalence and risk factors for cattle anaplasmosis, babesiosis, and trypanosomiasis in a Brazilian semiarid region. Rev Bras Parasitol Vet 2013; 22(2): 207-213. PMid:23802235. http://dx.doi. org/10.1590/S1984-29612013005000022

Cruz CD, Ferreira FM, Pessoni LA. Biometria aplicada ao estudo da diversidade genética. Viçosa: UFV; 2011. 
Drummond RO, Ernest SE, Trevino JL, Gladney WJ, Grhham OH. Boophilus annulatus and Boophilus microplus: laboratory tests for insecticides. J Econ Entomol 1973; 66(1): 130-133. PMid:4690254.

Dumler JS, Barbet AF, Bekker CP, Dasch GA, Palmer GH, Ray SC, et al. Reorganization of genera in families Rickettsiaceae and Anaplasmataceae in the order Rickettsiales: unification of some species of Ehrlichia with Anaplasma, Cowdria with Ehrlichia and Ehrlichia with Neorickettsia, descriptions of six new species combinations and designation of Ehrlichia equi and 'HGE agent' as subjective synonyms of Ehrlichia phagocytophila. Int J Syst Evol Microbiol 2001; 51(Pt 6): 2145-2165. PMid:11760958. http://dx.doi.org/10.1099/00207713-51-6-2145

Farias NAR. Diagnóstico e Controle da Tristeza Parasitária Bovina. Guaíba: Agropecuária; 1995.

Figueroa JV, Chieves LP, Johnson GS, Buening GM. Multiplex polymerase chain reaction based assay for the detection of Babesia bigemina, Babesia bovis and Anaplasma marginale DNA in bovine blood. Vet Parasitol 1993; 50(1-2): 69-81. http://dx.doi.org/10.1016/03044017(93)90008-B

Folly MM, Pereira MAVC, Emmott VP, Vita GF, Madruga R. Ocorrência de Babesia sp. em bezerros mestiços, por meio de testes sorológicos, em Campos dos Goyatacazes, RJ, Brasil. Rev Bras Saúde Prod An 2009; 10(1): 44-51.

Gonçalves PM. Epidemiologia e controle da tristeza parasitária bovina na região sudeste do Brasil. Cienc Rural 2000; 30(1): 187-194. http:// dx.doi.org/10.1590/S0103-84782000000100030

Guimarães AM, Carvalho AHO, Daher DO, Rocha CMBM, Hirsch C. Soroprevalência e fatores de risco para Babesia bovis em rebanhos leiteiros na região sul de Minas Gerais. Ciênc Agrotec 2011; 35(4): 826-832. http:// dx.doi.org/10.1590/S1413-70542011000400024

Instituto Brasileiro de Geografia e Estatística - IBGE. Produção da pecuária municipal [online]. 2010 [cited 2011 Out 23]. Available from: http:// www.ibge.gov.br/home/estatistica/economia/ppm/2010/default.shtm.

Jonsson NN, Bock RE, Jorgensen WK, Morton JM, Stear MJ. Is endemic stability of tick-borne disease in cattle a useful concept? Trends Parasitol 2012; 28(3): 85-89. PMid:22277132. http://dx.doi.org/10.1016/j. pt.2011.12.002

Kessler RH, Madruga CR, Shenck MAM. Babesiose cerebral por Babesia bovis (Babes, 1888, Starcovici, 1983) em bezerros do Estado do Mato Grosso do Sul. Pesq Agropec Bras 1983; 22: 1225-1230.

Kessler RH. Considerações sobre a transmissão de Anaplasma marginale. Pesq Vet Bras 2001; 21(4): 177-179. http://dx.doi.org/10.1590/S0100736X2001000400009

Kocan KM, De La Fuente J, Blouin EF, Garcia-Garcia JC. Anaplasma marginale (Rickettsiales: Anaplasmataceae): recent advances in defining host-pathogen adaptations of a tick-borne rickettsia. Parasitology 2004; 129: S285-S300. PMid:15938516. http://dx.doi.org/10.1017/ S0031182003004700

Kuhn C, Thaller G, Winter A, Bininda-Emonds ORP, Kaupe B, Erhardt G, et al. Evidence for multiple alleles at the DGAT1 locus better explains a quantitative trait locus with major effect on milk fat content in cattle. Genetics 2004; 167(4): 1873-1881. PMid:15342525 PMCid:PMC1470998. http://dx.doi.org/10.1534/genetics.103.022749

Madruga CR, Aycardi E, Kessler RH, Schenk MAM, Figueiredo GR, Curvo JBE. Níveis de anticorpos anti-Babesia bigemina e Babesia bovis, em bezerros da raça nelore, Ibagé e cruzamentos de nelore. Pesq Agropec Bras 1984; 19(9): 1163-1168.
Madruga CR, Araújo FR, Marques APC, Carvalho CME, Cusinato FQ, Crocci AJ, et al. Desenvolvimento de uma prova de imunoadsorção enzimática para detecção de anticorpos contra Babesia bovis. Pesq Vet Bras 2000; 20(4): 167-170. http://dx.doi.org/10.1590/S0100736X2000000400007

Mahoney DF, Ross DR. Epizootiological factors in the control of bovine babesiosis. Aust Vet J 1972; 48(5): 292-298. http://dx.doi. org/10.1111/j.1751-0813.1972.tb05160.x

Marana ERM, Alfieri AA, Andrade GM, Freire RL, Garcia JL, Vidotto O. Comparação dos testes sorológicos de Imunofluorescência Indireta, Conglutinação Rápida, ELISA indireto e ELISA por competição para a detecção de anticorpos contra o Anaplasma marginale em soros de bovinos de diferentes áreas enzoóticas. Semin., Cienc. Agrar 2006; 27(4): 629-638.

Marana ERM, Dias JA, Freire RL, Vicentini JC, Vidotto MC, Vidotto O. Soroprevalência de Anaplasma marginale em bovinos da regiáo Centro-Sul do estado do Paraná, Brasil, por um teste imunoenzimático competitivo utilizando proteína recombinante MSP5-PR1. Rev Bras Parasitol Vet 2009; 18(1): 20-26. PMid:19500456. http://dx.doi.org/10.4322/ rbpv.01801004

Martins TM, Neves LP, Olivia C, Fafetine JM, Rosario V, Domingos A. Molecular detection of Babesia spp. and other haemoparasitic infections of cattle in Maputo Province, Mozambique. Parasitology 2010; 137(6): 939-946. PMid:20128941. http://dx.doi.org/10.1017/ S003118200999196X

Mason CA, Noval RAI. The transfer of Boophilus microplus (Acarina: Ixodidae) from infested to uninfested cattle under field conditions. Vet Parasitol 1981; 8(2): 185-188. http://dx.doi.org/10.1016/03044017(81)90046-7

Moura AB, Vidotto O, Yamamura MH, Vidotto MC, Pereira ABL. Studies on the Anaplasma marginale Theiler, 1910 infection in Boophilus microplus (Canestrini, 1887) using 'nested' PCR. Rev Bras Parasitol Vet 2002; 12(1): 27-32.

Oliveira-Sequeira TCG, Oliveira MCS, Araujo JP, Amarante AFT. PCRbased detection of Babesia bovis and Babesia bigemina in their natural host Boophilus microplus and cattle. Int J Parasitol 2005; 35(1): 105-111. PMid:15619521. http://dx.doi.org/10.1016/j.ijpara.2004.09.002

Osaki SC, Vidotto O, Marana ERM, Vidotto MC, Yoshihara E, Pacheco $\mathrm{RC}$, et al. Ocorrência de anticorpos anti Babesia bovis e estudo sobre a infecção natural em bovinos da raça nelore, na regiáo de Umuarama, Paraná, Brasil. Rev Bras Parasitol Vet 2002; 11(2): 77-83.

Pereira DAA. Avaliação e otimização de reaçôes da polimerase em cadeia para diagnóstico molecular e estudo epidemiológico de Babesia bovis [Dissertaçáo]. Campo Grande: Universidade Federal de Mato Grosso do Sul; 2006.

Ribeiro MFB, Lima JD, Salcedo JHP. Attempted transmission of Anaplasma marginale by infected Boophilus microplus. Arq Bras Med Vet Zootec 1996; 48(4): 397-402.

Santana AP, Linhares GFC, Murata LS, Bernal FE, Torres FA, Madruga CR. Dinâmica da infecção natural por Babesia bigemina em bezerros a partir do nascimento detectado pela reação em cadeia da polimerase. Ciênc Anim Bras 2008; 9(3): 721-730.

SAS Institute Inc. Statistical Analysis System user's guide. Version 9.1. Cary; 2003.

Shimada MK, Yamamura MH, Kawasaki PM, Tamekuni K, Igarashi M, Vidotto O, et al. Detection of Anaplasma marginale DNA in Larvae of Boophilus microplus ticks by Polymerase Chain Reaction. 
Ann N Y Acad Sci 2004; 1026: 95-102. PMid:15604475. http://dx.doi. org/10.1196/annals.1307.012

Smeenk I, Kelly PJ, Wray K, Musuka G, Trees AJ, Jongejan F. Babesia bovis and Babesia bigemina DNA detected in cattle and ticks from Zimbabwe by polymerase chain reaction. J S Afr Vet Assoc 2000; 71(1): 21-24. PMid:10949512. http://dx.doi.org/10.4102/jsava.v71i1.671

Souza JCP, Soares CO, Madruga CR, Massard CL. Prevalência de anticorpos anti Anaplasma marginale (Rickettsiales: Anaplasmataceae) em bovinos na mesorregião do médio Paraíba. Cienc Rural 2001; 31(2): 309-314. http://dx.doi.org/10.1590/S0103-84782001000200019

Sparagano OAE, Allsopp MTEP, Mank RA, Rijpkema SGT, Figueroa JV, Jongejan F. Molecular detection of pathogen DNA in ticks (Acari: Ixodidae): a review. Exp Appl Acarol 1999; 23(12): 929-960. PMid:10737729. http://dx.doi.org/10.1023/A:1006313803979

Stich RW, Kocan KM, Palmer GH, Ewing SA, Hair JA, Barron SJ. Transstadial and attempted transovarial transmission of Anaplasma marginale by Dermacentor variabilis. Am J Vet Res 1989; 50(8): 1377 1380. PMid:2782719.
Terkawi MA, Alhasan H, Huyen NX, Sabagh A, Awier K, Cao S, et al. Molecular and serological prevalence of Babesia bovis and Babesia bigemina in cattle from central region of Syria. Vet Parasitol 2012; 187(1-2): 307-311. PMid:22265803. http://dx.doi.org/10.1016/j. vetpar.2011.12.038

Torioni De Echaide S, Knowles DP, McGuire TC, Palmer GH, Suarez CE, McElwain TF. Detection of cattle naturally infected with Anaplasma marginale in a region of endemicity by nested PCR and a competitive enzyme-linked immunosorbent assay using recombinant major surface protein 5. J Clin Microbiol 1998; 36(3): 777-782. PMid:9508311. PMCid:PMC104624.

Thrusfield M. Veterinary epidemiology. London: Butterworth; 1986.

Vidotto O, Marana ERM. Diagnóstico em anaplasmose bovina. Cienc Rural 2001; 31(2): 361-368. http://dx.doi.org/10.1590/S010384782001000200028

Zaugg JL, Stiller D, Coan ME, Lincoln SD. Transmission of Anaplasma marginale Theiler by males of Dermacentor andersoni Stiles fed on an Idaho field-infected, chronic carrier cow. Am J Vet Res 1986; 47(10): 2269-2271. PMid:3777655. 